\title{
Erratum zu: Lösungsorientiertes Team-Coaching
}

\section{Erratum zu:}

\section{J. Middendorf und B. Furman, Lösungsorientiertes \\ Team-Coaching, essentials, https://doi.org/10.1007/978-3-658-26540-3}

Die originale Version dieses Buches wurde ohne die Seite „Über die Autoren“ publiziert. Diese ist nun ergänzt.

Im Impressum ist nachstehender Copyright-Vermerk hinzugefügt:

,reteaming ${ }^{\circledR}$ ist ein markenrechtlich geschützter Begriff. Rechteinhaber ist das Helsinki Brief Therapy Institute (Referenznummer LTI001), vertreten durch Ben Furman." 